\title{
Good Environmental Governance Reinforcement as a Strategy to Overcome Forest and Land Fires in Pelalawan, Riau
}

\author{
Mustiqowati Ummul Fithriyyah ${ }^{1}$, Sri Suwitri ${ }^{2}$, Y. Warella ${ }^{3}$, Febri Yuliani ${ }^{4}$ \\ \{mustiqoumulfitria@uin-suska.ac.id ${ }^{1}$ \} \\ Universitas Islam Negeri Sultan Syarif Kasim Riau, Indonesia ${ }^{1}$ \\ Universitas Diponegoro, Indonesia ${ }^{2,3}$ \\ Universitas Riau, Indonesia ${ }^{4}$
}

\begin{abstract}
Forest and land fires are a form of environmental disturbance. The significant negative impacts caused by forest fires include ecological damage, biodiversity loss, decrease in the economic value of forests and soil productivity, micro and global climate change, and its smog disturbs the public health and transportation on land, river, lake, sea, and air. This study aims to find aspects that drive the reinforcement of good environmental governance as a strategy to overcome forest and land fires in Pelalawan Regency, Riau Province. The method used in this research is a qualitative descriptive based on a literature review and interview results collected, then the data obtained is selected according to the needs and groups them according to the type and form. The results of the study state that the reinforcement of good environmental governance in overcoming forest and land fires can be done by developing regional institutional capacity through several aspects, which are; organizational structure, resources, and political aspects. Capacity building for regional governments will be carried out through a series of programs that will be organized based on the needs of the area known through its process. Collaborating with units in the Ministry of Environment and Forestry and other institutions in the region and in the central, the programs are implemented in the form of training to improve human resources, institutions, regulations, and other supporting facilities. In addition, an assistance program for the region was also carried out in developing and implementing regional regulations in the environmental field, and a facilitation program for the regions to obtain funding. The form of the relationship to be developed is not limited to the relationship between the central and the regions, but also between one region and another.
\end{abstract}

Keywords: Forest and Land Fires, Good Environmental Governance, Institutional Capacity.

\section{Introduction}

Forest and land fires are one of the disturbances which often happen. The significant negative impacts caused by forest fires include ecological damage, biodiversity loss, decrease in the economic value of forests and soil productivity, micro and global climate change, and its smog disturbs the public health and transportation on land, river, lake, sea, and air [1]. Even the smog and haze caused by Indonesia's forest fires have recently crossed national borders. 
In the case of forest and land fires, people know the term of the fire triangle. This fire triangle is the basis/precondition for fire, which is: O2 (oxygen), heat/ignition source, and fuel. There is also the Fire Behavior Triangle which explains what influences the forest fires, which are: type of fuel, weather, and topography. Fires often happen in peatlands.

Peatland is a type of aggregate which is formed by the decomposition of organic matter. Therefore, the conditions are quite humid, so fires that occur are fires below the surface of the land that are quite difficult to detect and control. In Indonesia, more than $90 \%$ is humancaused which is done both intentionally and unintentionally [2]. This happens because the majority of forest and land fires in Indonesia occur from land clearing activities, forest conservation into plantations, by burning methods. This fuel method was chosen because it is more economical.

These routine fires are not only caused by changes in the ecological chain, but are also influenced by the intentions of large-scale plantation business actors in land clearing, and the negligence of Industrial Plantation Forest (Hutan Tanaman Industri or HTI) business actors in carrying out production and environmental governance [3].

Land burning for land clearing activities in plantation area, which is carried out as a costsaving step for land clearing rather than a manual step, is done because it is considered capable of fertilizing the area of land to be used so that it will also reduce costs for fertilization such as fertilizer. On peatlands, burning will speed up the process of water subsidence and evaporation, so the company doesn't need to build canals for drainage. Moreover, mobilization of heavy equipment in the land clearing process requires permits and payment of levies outside of taxes, this has an impact on the loss of potential revenue which should be accepted by the region/country.

The National Disaster Management Agency (BNPB) states the extent of forest and land fires (karhutla) in Indonesia from January to August 2019 reached 328,724 hectares (Ha). The most affected area is Riau. BNPB Data, Information, and Public Relations Director, Agus Wibowo, when contacted by ANTARA from Pekanbaru on Tuesday (9/10/2019) said that Riau Province was the largest area hit by the fires in Sumatra, which reached 49,266 hectares (Ha).

The distribution of fires in Riau Province from 2017 to 2019, can be seen in the figure 1:

Spread Graph Hot Spot in Riau 2017 - 2019

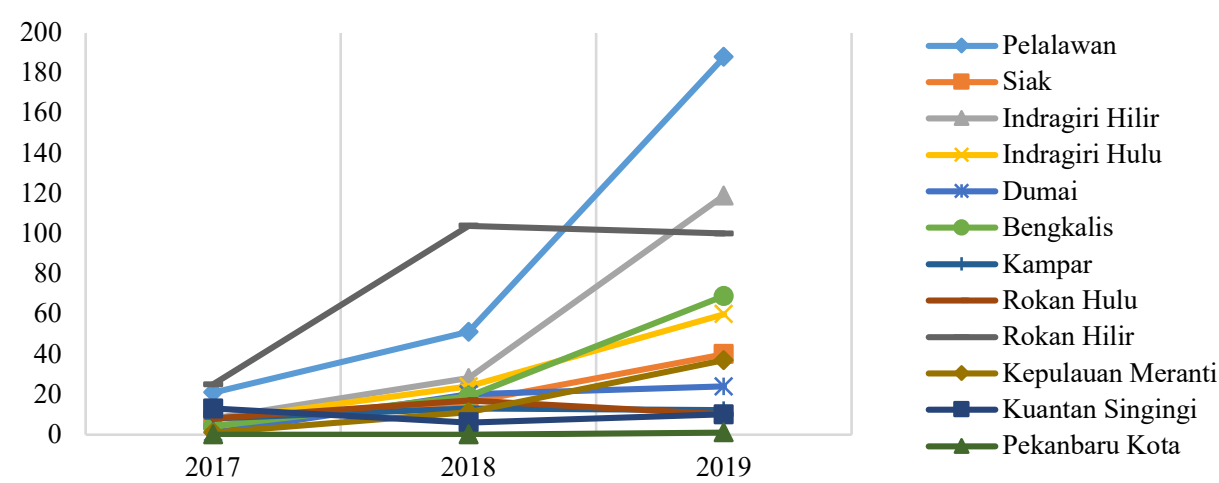

Fig. 1. Chart of Fires Distribution in Riau (Source: SiPongi, Forest and Land Fires System of Ministry of Environment and Forestry 2017-2019). 
The government plays the most important role in the matter of forest and land fires because they are the determinant in implementing policies on people who are responsible for forest fires, especially in Industrial Plantation Forest companies - which based on the data are the biggest actors in forest and land fires. However, this matter of forest and land fires requires the synergy of cooperation between sectors; such as the government, the private sector, and the community. This is what we call the concept of good governance.

Good Environmental Governance is an idea proposed by the Ministry of Environment and Forestry as an effort to realize good governance. The core of the application of Good Environmental Governance is to strengthen the coordination system between the government, the private sector and the community in creating a good environment so that the government can get the right response to solve urgent environmental problems.

From the description above, the researchers are interested in conducting in-depth research on how to strengthen institutional capacity in the government through the reinforcement of good environmental governance as a strategy to overcome forest and land fires in Pelalawan Regency. This study aims to find aspects that support the reinforcement of good environmental governance in Pelalawan Regency as a strategy to overcome forest and land fires.

\section{Methods}

This research is qualitative descriptive research which is based on a literature review and interview results collected according to the information needed, then the data obtained is selected according to the needs and groups them according to the type and form. Furthermore, the data is processed and analyzed qualitatively following the subject matter to get a deep understanding.

The selection of this qualitative descriptive approach is based on consideration; because researchers intend to get an in-depth picture of the government's efforts in controlling forest and land fires in Riau. This research is also holistic (comprehensive, inseparable) because this study looks at the overall activities carried out by forest and land fire control organizations in Pelalawan Regency, which are mostly based on the overall social situation that is synergistically interconnected.

To obtain the data, researchers went directly to the field to see the efforts made by the government to overcome forest and land fires in the context of good environmental governance. Data were collected using some methods, such as observation, documentation, and interviews with informants taken from; Riau Environment and Forestry Agency and Riau Regional Disaster Management Agency.

In this research, the data analysis used is qualitative. The qualitative paradigm requires that data analysis be carried out continuously throughout the research process so that each step is interconnected. The data analysis process in this study adopted Miles and Huberman's thoughts which included 3 (three) components of analysis, which are: data reduction, data display and conclusion drawing [4]. Then the analysis is carried out by combining synergistically the three components. Data reduction, used as a form of analysis that sharpens, classifies, directs, and organizes data in such a way that conclusions can be drawn [5]. Display of data, intended to display various data that has been obtained as information related to land and forest fires. Research limits a display as a collection of structured information that allows the conclusion drawing or action taking. Conclusions drawing, researchers try to analyze and 
search for meaning from the data collected through a continuous verification process, then conclusions will be drawn.

\section{Discussion}

\subsection{Forest and Land Fires and Burning}

The cause of the large numbers of forest and land fires in Pelalawan Regency is related to large-scale land clearing activities for oil palm plantations, where after the Forest Concessions (Hak Pengusahaan Hutanor/HPH) harvests valuable timber, there will be a status change of land and forest which becomes an oil palm plantation or Industrial Plantation Forestry. In preparing the land, the developer always uses fire to clean the fuel found above the surface of the land, because oil palm plants need land that is clean from stumps and tree trunks. With climatic conditions that make the weather hotter, it will cause an increasing number of fires.

A data from one of the informants stated that the cost of land clearing by burning is only a quarter of the cost of land clearing without burning (PLTB), which means that there is no economic incentive for companies to carry out land clearing without burning. Land clearing by burning only takes 28 working days, while mechanical land clearing for primary forests requires 80 working days plus 12 hours of tractor work and for secondary forests requires 53 working days plus 10 hours of tractor work. These numbers have implications for costs and investment.

The burning land habit is usually done at the beginning and mid of the dry season. From the socialization of forest and land fires in Pelalawan Regency. Most villagers in Pelalawan Regency burned land during preparation and cleaning by using a mixed-method, which is between burning and not burning. The low-cost factor is the main trigger for this behavior. The following is an excerpt from an interview with one of the people in Pelalawan with the initial $\mathrm{H}$ :

"Land clearing by burning is preferred because it is more economical. In comparison, per hectare of burned land costs \$10-20, while mechanically cleared land requires \$200 per hectare", (7 September 2019).

On the other hand, the goal of the community for doing the burning is to anticipate planting in the coming rainy season, moreover, the fuel in the dry season is easily dry and the next goal is that land clearing can be done as soon as possible.

\subsection{Philosophy of Good Environmental Governance}

Environmental Governance is built on two concepts, which are management and environmental governance [6]. The concept of environmental governance itself can be defined as a collection of values and norms that guide or regulate relations between countries and civil society in the use, supervision, and management of the natural environment. These values and norms are expressed in a complex chain consisting of regulations, policies, and institutions that govern an organizational mechanism in articulating broad targets and specific planning targets of environmental management. 
Environmental governance provides a conceptual framework in which public and private behavior are regulated in favor of more ecologically oriented arrangements. The framework forms a reciprocal relationship between people (global, regional, national and local) in dealing with the access and use of environmental goods and services and binds them (at any level) with certain specific environmental ethics.

\subsection{Development of Regional Institutional Capacity towards Good Environmental Governance}

The institutional framework is the performance of the design of the organization's body which always includes perspectives of descriptive and perspective thinking. Descriptive perspective based on the principle of understanding institutional conditions that have been formed in a prescriptive. Perspective is the performance of future institutions that are patched or will be developed. The institutional framework is always reflected by the presence of concrete structures, behavioral structures, and analytic structures. The bureaucratic structure is structural which is manifested in the form of bodies, agencies, offices, and sections. While the structure of behavior is reflected in the quantity and quality of human resources. Moreover, the analytic structure refers more to the effectiveness and efficiency of the interrelation between concrete structures and behavioral structures [7].

In creating institutions that have capabilities in the environmental field, local governments need to conduct a study by considering comprehensively, both from the financial, institutional, and cultural dimensions that must be aligned with the demands of public services. The financial dimension relates to funding capability, the institutional dimension relates to resource development and the structural dimension emphasizes the importance of education, socialization and policy adaptation. Policies to realize the principles of regional development that are environmentally friendly and sustainable must be by the vision, mission, and regional strategies.

\subsection{Aspects that Support the Reinforcement of Good Environment Governance}

\subsubsection{Organizational Structure}

The organizational structure is the result of the design between the functions to be carried out by the organizational unit with the existing formal structure. The organizational structure influences the performance of the organization itself, with the organizational structure, each task, and responsibility of each employee will be seen so that there is no overlap in carrying out the task. The Pelalawan BPBD (Regional Disaster Management Agency) and the Department of Animal Husbandry Pelalawan have a special section on land and forest fires (Regdamkar) but have not been well integrated into their programs. The existence of the organization (Regdamkar) has become less effective in the handling of land and forest fires because it is only focused on extinguishing it, it is not yet massive in moving towards recovery and prevention efforts. Several organizations involved in controlling forest and land fires in Pelalawa are explained in the table 1.

Table 1. List of Forest and Land Fires Control Stakeholders in Pelalawan Regency

\begin{tabular}{|c|c|}
\hline No & Stakeholders \\
\hline 1 & Regional Disaster Management Agency (BPBD) of Pelalawan Regency \\
\hline
\end{tabular}




\begin{tabular}{|c|l|}
\hline 2 & Dinas Kehutanan Kabupaten Pelalawan \\
\hline 3 & Dinas Perkebunan \& Peternakan Kabupaten Pelalawan \\
\hline 4 & Dinas Lingkungan Hidup Kabupaten Pelalawan \\
\hline 5 & Satpol PP \& Damkar Kabupaten Pelalawan \\
\hline 6 & Polres Pelalawan \\
\hline 7 & Dinas Kesehatan Kabupaten Pelalawan \\
\hline 8 & Fire Care Community (Masyarakat Peduli Api/MPA) \\
\hline 9 & Fire Care Farmer Community (Kelompok Tani Peduli Api/KTPA) \\
\hline 10 & Palm Oil Plantation Companies in Pelalawan \\
\hline 11 & Brigade (Manggala Agni) \\
\hline 12 & $\begin{array}{l}\text { Task Force of Fire Control of Forest and Land Fires of Pelalawan Regency } \\
\text { (Satlakdamkarhutla) }\end{array}$ \\
\hline 13 & Task Force of Forest and Land Fires of Pelalawan Regency (Satgas Karhutla) \\
\hline 14 & Fire Care Communityof ( Regu Pemadam Api /RPA) Pelalawan Regency \\
\hline 15 & $\begin{array}{l}\text { Regional Military Command for Forest and Land Fires of Riau Province } \\
\text { (Puslakdamkarhutla) }\end{array}$ \\
\hline 16 & Regional Disaster Management Agency (BPBD) of Riau Province \\
\hline 17 & Meteorology, Climatology, and Geophysical Agency (BMKG) of Riau Province \\
\hline 18 & Dinas Lingkungan Hidup dan Kehutanan Provinsi Riau \\
\hline 19 & Indonesian National Armed Forces (Army-Air Force/TNI -AD-AU) \\
\hline 20 & NGO \\
\hline
\end{tabular}

Source: Processed by the researcher (2019).

A joint organization for extinguishing forest and land fires has also been formed by the Regent. However, it is adhocracy or not permanent, which is created during the dry season, which is connoted to the fire season. In addition, the performance of this joint organization will be better if it is fixed as a permanent organization and not merely incidental.

\subsubsection{Resources}

Resources are the most important part of an organization, the absence of adequate resources in the organization causes many obstacles to be faced in achieving organizational goals. The resources referred here are in the form of human resources, facilities, and infrastructure available, as well as budget allocations or available funds inboth quality and quantity.

Based on information obtained from informants, the budget for funding the forest and land fire prevention is still minimum. In a joint organization, there is no independent budget. 
The budget funds come from each service or agency that has a forest and land extinguish forest and land fires program.

\subsubsection{Politics}

Political factors are matters which relate to the balance of state power that affects security and involvement which will affect the organization's condition to work optimally. Political factors greatly influence the process of strengthening good environmental governance, this can be seen from the number of cases of forest fires that can be handled, from cases contained in reports or media reports about forest and land fires that occur. The lack of support from the political elite for law enforcement against the burning of forests and land which causes forest destruction and forest and land fires in Pelalawan Regency continues to happen.

\subsection{Government Position and Role in Good Environmental Governance Reinforcement as the Strategy to Control Forest and Land Fires in Pelalawan Regency}

In term of good environmental governance, there are several characteristics that must be integrated in every policy which has the urgency to implement environmental development policy related to several things, they are: empowerment, society participation, and public information access, transparency, democratic decentralization, ecosystem support confession and sustainability, consistency and harmony, clarity and enforceability.

Generally, there were actions taken by the government of Riau Province in tackling the forest and land fire. However, forest and land fire treatment are still in a certain spot and disintegrated. So, this problem cannot be completely solved and not all forest and land fire mitigations are done. The mitigation includes preventive stage, readiness, and emergency response done in eleven risky regencies/cities, including Pelalawan Regency.

Supervision can be identified with command and control rules. However, the implementation of those rules -related to forest and land handling effort does not work effectively. The ineffectiveness is caused by (1) almost same standard-setting yet environment capacity is not same, (2) fine calculation which charged on ex-ante is not always appropriate with the actual condition, (3) high enforcement cost, and (4) in most case the cost is not worth with the benefit.

The supervision and regulation intensity by the government on the performance of the managers of natural resources related to forest and land fire has been done yet the result has not been maximized. It is caused by the lack of penalty which emerged the deterrent effect from the arsonist. The difficulties happen is the proofing process to ensure the air pollution produced by forest and land fire is caused by forest and land fire in the concession area of the perpetrators. Furthermore, there are still different perceptions between the law enforcement officers in deciding rules that will be alleged to the perpetrators.

\section{Conclusion}

Forest and land fires in Pelalawan Regency are caused by land utilization from companies and farmers in peatland. The forest and land fires factor that comes from farmers is their burning habit for preparing the land, and the presumption that burning land will fertilize 
the soil. Besides that, there is still disintegrated coordination between the Government in Pelalawan Regency that runs the program for overcoming the forest and land fires.

Another important factor is government weakness in cracking down the violation from the company or people that use fire in the land clearing; it can be done by revocation or suspension of land management permits for companies and social sanctions for the community.

The suggestion from this research is structurally changing in controlling the forest and land fires so that it can be completely integrated with the availability of adequate resources and firm politic support from various parties in overcoming the forest and land fires.

\section{References}

[1] Absori, A. Sunanda, and A. Fitriciada, Penegakan hukum lingkungan \& antisipasi dalam era perdagangan bebas. Muhammadiyah University Press, 2000.

[2] B. H. Weston, "Hak-hak Asasi Manusia dalam Masyrakat Dunia: Isu dan Tindakan." Penyunting: T. Mulya Lubis, Yayasan Obor Indonesia, Jakarta. Bedah Mayat ..., 1993.

[3] K. Hardjasoemantri, "Никит Tata Lingkungan." Gadjah Mada University Press, Yogyakarta, 1999.

[4] M. B. Miles, A. M. Huberman, M. A. Huberman, and M. Huberman, Qualitative data analysis: An expanded sourcebook. sage, 1994.

[5] S. Arikunto, "Research procedure a practical approach," Jakarta PT Rineka Reserv., 2010.

[6] E. Santosa, "Kelembagaan Lingkungandalam Era Otonomi Daerah," FISIP Univ. Semarang, 2001 .

[7] E. Santosa, "Ilmu Politik Lingkungan," FISIP Univ. Semarang, 2004. 